\title{
Minimally invasive surgery for esophageal cancer - benefits and controversies
}

\author{
Grzegorz Wallner, Witold Zgodziński, Wioletta Masiak-Segit, Tomasz Skoczylas, Andrzej Dąbrowski \\ II Chair and Department of General and Gastrointestinal Surgery and Surgical Oncology of the Alimentary \\ Tract, Medical University of Lublin
}

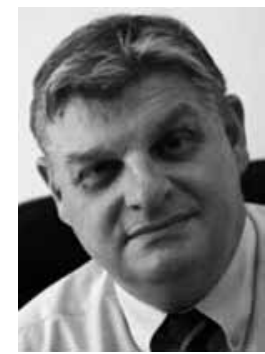

Kardiochirurgia i Torakochirurgia Polska 2014; 11 (2): 151-155

\begin{abstract}
Open esophagectomy (OE) requires extensive surgery and is associated with significant morbidity and mortality. Furthermore, the long-term results of esophageal cancer surgery are not satisfactory; hence, the best surgical approach is constantly under debate. During the last twenty years, minimally invasive esophagectomy (MIE) employing laparoscopy and/ or thoracoscopy has been introduced in a growing number of centers worldwide. To date, several studies have demonstrated that MIE has better outcomes than OE, as it results in shorter hospital stay and decreased overall morbidity. However, the length of operating time in MIE is increased in comparison to OE. The survival benefit has been demonstrated to be similar in OE and MIE. Highly advanced laparo-thoracoscopic skills are required to perform MIE; along with the relatively long learning curve, this makes MIE feasible only in high-volume, experienced university surgical centers. There is a need for further large-scale comparative studies to prove the superiority of MIE over open surgery.
\end{abstract}

Key words: minimally invasive esophagectomy.

\section{Introduction}

Esophageal cancer is one of the least common and most deadly gastrointestinal tract neoplasms. In 2010 in Poland, the standardized incidence ratio for esophageal cancer was 3.3/100,000 for men and 0.6/100,000 for women [1]. Patient survival is short, and the incidence/mortality ratio for both sexes was 0.8 in 2010 [2]. For many years, the primary method of treating patients with advanced esophageal cancer (EC) has been surgical treatment, which is associated with significant injury. Traditional surgery employs access via thoracotomy and laparotomy with thoracic or cervical anastomosis. The surgery is burdened with the highest perioperative mortality rate among all gastrointe-

\section{Streszczenie}

Klasyczna, otwarta ezofagektomia (OE) wymaga bardzo inwazyjnej operacji i wiąże się ze znacznym odsetkiem powikłań i śmiertelności. Odległe wyniki operacji raka przełyku również nie są zadowalające, dlatego też optymalne leczenie chirurgiczne jest przedmiotem ciągłej dyskusji. W ciągu ostatnich 20 lat w coraz większej liczbie ośrodków na całym świecie wprowadzana jest minimalnie inwazyjna ezofagektomia (MIE), wykorzystująca dostęp laparoskopowy i/lub torakoskopowy. Dotychczas w wielu badaniach potwierdzono lepsze wyniki MIE w porównaniu z OE, tj. krótszy pobyt w szpitalu i niższy współczynnik powikłań okołooperacyjnych. Jednakże czas operacji MIE jest dłuższy w porównaniu z OE. Wyniki całkowitego przeżycia po MIE są porównywalne z wynikami OE. Do przeprowadzenia operacji MIE wymagane są bardzo zaawansowane umiejętności w technikach laparo- i torakoskopowych, przy dość długiej krzywej uczenia, co sprawia, że ten rodzaj leczenia może być dostępny tylko w doświadczonych chirurgicznych ośrodkach uniwersyteckich. Aby wykazać przewagę MIE nad metodą otwartą, potrzebne są dalsze, duże badania porównawcze.

Słowa kluczowe: minimalnie inwazyjna ezofagektomia.

stinal tract procedures, reaching $18-20 \%$ according to some reports [3-5]. Treatment outcomes in specialized centers are better, but perioperative mortality remains significant. Technological development as well as improved preoperative assessment, surgical technique, and postoperative care play a significant role in the improvement of surgical treatment outcomes. The premise of minimally invasive techniques in esophageal surgery is to maintain the therapy effectiveness and quality of traditional operations while reducing perioperative injury. The techniques are based on the principle of "delicate dissection" in order to minimize the damage. Reducing the extent of injury should result in a smaller risk of complications. Moreover, minimally invasive techniques are widely accepted by patients and medical

Address for correspondence: prof. dr hab. Grzegorz Wallner, $2^{\text {nd }}$ Department and Clinic of General Surgery, Gastro- and Gastrointestinal Tumors, Medical University of Lublin, Staszica 16, 20-081 Lublin, Poland, tel. 8153241 27, fax 81532 88 10, e-mail: gt_wallner@interia.pl 
personnel. Reducing the negative psychological impact of open surgery leads to the improvement of patient satisfaction from the employed treatment [6]. The first reports of thoracoscopic esophagus removal were published over 20 years ago $[7,8]$. The premises of thoraco-laparoscopic minimally invasive esophagectomy (MIE) remain identical as those of open surgery (oncological radicality RO, 2- or 3 -field lymphadenectomy). However, certain reservations remain concerning the oncological value of MIE as well as the risks and costs related to these technically demanding and time-consuming surgical procedures. The key factor of MIE is the proper qualification of patients, which should be based on the precise evaluation of the stage of the neoplastic disease. The patients undergo diagnostic examinations: endoscopic ultrasound and computed tomography of the chest and abdominal cavity. Some centers also employ full-body positron emission tomography (PET). In patients in whom locoregional disease is suspected, laparoscopic and/or thoracoscopic evaluation is recommended. In preoperative assessment, laparoscopy is particularly useful in the case of lower esophageal adenocarcinoma; it is also more sensitive in the diagnosis of pathological lymph nodes as well as omental, peritoneal, and hepatic metastases. It is a safe procedure with a low rate of complications; concurrently, in the case of diffuse neoplastic disease, it allows the avoidance of redundant surgical procedures and expedites the start of palliative treatment. In the case of proximal tumors, the use of thoracoscopy in combination with pleural or mediastinal lymph node biopsy also improves preoperative evaluation by approximately $20 \%$ with regard to confirming lymph node or distal metastases [9].

\section{Indications for minimally invasive surgery for esophageal cancer}

Minimally invasive procedures are used in benign diseases of the esophagus. Most frequently, the method can be used in patients with persistent dysphagia resulting from digestive stenosis, end-stage achalasia, or extreme insufficiency of the esophageal passage in other functional diseases of the eso- phagus [10, 11]. Indications for the use of MIE techniques in cancer patients remain more controversial. In cases in which extensive lymphadenectomy is not required, MIE appears to be an ideal technique for treating changes such as severe dysplasia [12, 13]; however, in such cases, advanced endoscopic techniques remain a popular alternative [14]. Minimally invasive esophagectomy is more acceptable for invasive cancer; it is comparable to traditional resections in terms of outcome and causes less perioperative damage. The contraindications for MIE include massive pleural adhesions, previous lung surgery, extensive tumors, and local infiltration, especially of the respiratory system [15]. Extensive adhesions after abdominal surgery may constitute a contraindication for laparoscopy. Due to the necessity of prolonged one lung ventilation, the respiratory and circulatory systems of patients qualified for MIE should exhibit proper efficiency. Contraindications for MIE operations also include serious concomitant diseases, e.g. cirrhosis [16].

\section{Minimally invasive esophagectomy}

At present, there is still no clear consensus concerning the preferred operative technique in esophageal surgery. Transhiatal esophagectomy (THE) and transthoracic esophagectomy (TTE) are complex procedures which are usually employed in the treatment of patients suffering from esophageal cancer. As with open procedures, in the case of MIE, there is no agreement as to which specific operative method is superior. The most commonly used techniques are presented in Table I. The most important development in MIE was achieved by Luketich et al., who employed a thoracoscopic technique to dissect the esophagus with the patient lying on the left side and performed laparoscopic mobilization and reshaping of the stomach with the patient lying supine followed by typical neck anastomosis [17]. Notwithstanding, most authors suggest selecting the MIE technique individually for each patient in order to avoid intraoperative problems and complications. In the case of tumors located in $1 / 3$ of the upper thoracic esophagus, it is justifiable to employ the thoracoscopic approach, while the use of the laparoscopic transhiatal technique is warranted

Tab. I. The most common types of esophageal surgery, based on Yamamoto et al. [15]

\begin{tabular}{lccc} 
Surgical technique & Abdominal stage & Thoracic stage & Anastomosis \\
Open surgery (Ivor-Lewis) & Laparotomy & Thoracotomy & Thoracic \\
\hline Open transhiatal & Laparotomy & - & Cervical \\
\hline Open 3-field surgery (McKeown) & Laparotomy & Thoracotomy & Cervical \\
\hline Hybrid transthoracic surgery & Laparoscopy or manually assisted & Thoracotomy & Thoracic \\
\hline Transabdominal hybrid surgery & Laparotomy & Thoracoscopy & Thoracic \\
\hline Hybrid 3-field surgery & Laparotomy & Thoracoscopy & Cervical \\
\hline 3-field MIE & Laparoscopic or manually assisted & Thoracoscopy & Cervical \\
\hline Transthoracic MIE surgery & Laparoscopic or manually assisted & Thoracoscopy & Thoracic \\
\hline Esophageal invagination & Laparoscopic or manually assisted & - & Cervical \\
\hline Transhiatal MIE surgery & Laparoscopic or manually assisted & - & Cervical \\
\hline
\end{tabular}


for the distal esophagus. Laparoscopic surgical tools are introduced through $5 \mathrm{~mm}$ ports: one located in the right subcostal region and two in the left subcostal region. The camera is inserted through a trocar placed above the navel. An additional $10 \mathrm{~mm}$ trocar is placed at the midaxillary line. Short gastric vessels are divided with a harmonic scalpel. The left gastric artery is dissected up to the celiac trunk. Lymph nodes and fat tissue are removed from the vicinity. Subsequently, the stomach is pulled upwards, and the left gastric vessels are cut with a vascular stapler. A linear stapler is used to construct a gastric tube. Feeding jejunostomy is introduced through one of the left abdominal trocar holes. After the abdominal stage of the surgery is completed, the patient is placed on the left side, and right lung ventilation is turned off. During dissection, the same rules apply as in open surgery. The azygos vein is divided using a vascular stapler. The whole esophagus should be carefully dissected together with the surrounding mediastinal lymph nodes. After its removal, the next stage of the surgery consists in creating an anastomosis. This can be achieved with both staplers and manual suturing techniques. Mechanical anastomosis is often performed by means of a circular stapler introduced through the patient's mouth. The risk of a leak in an anastomosis created in this manner does not exceed $10 \%$ and is comparable with other stapler techniques [18]. The gastroesophageal anastomosis is tightened with a pedicled greater omental flap. There are no MIE experiences involving the reconstruction of gastrointestinal tract continuity using other substitutes (the colon or small intestine). According to Hoppo et al., laparoscopic surgery with esophageal invagination performed through a neck incision (stripping) is the least invasive technique for esophagectomy; its more commonly used variant is laparoscopic inversion esophagectomy (LIE). This type of surgery may always be considered in benign diseases of the esophagus, severe dysplasia, T1NO tumors, and in view of contraindications for thoracotomy. For locally advanced cancer of the middle and upper segments of the thoracic esophagus, the author recommends 3-field MIE in the following order: abdominal stage, thoracic stage, neck anastomosis. For tumors in the lower segment of the esophagus, thoracoscopic and laparoscopic 2-field MIE with thoracic anastomosis may be preferred [19]. Minimally invasive operations must meet all oncological criteria for esophagus removal, which are also used in the case of open surgery. Above all, the surgery must adhere to the principles of oncological radicality with the preservation of distal, proximal, and radial (RO) margins, two/ three-field lymph node dissection, and oncological asepsis of the laparo/thoracoscopic ports. The specific type of surgery should be selected individually depending on the type of cancer, TNM staging, and the availability of endoscopic methods. Patients undergoing MIE operations should be monitored and followed up in the same manner as those undergoing traditional surgery [20, 21].

\section{Robotically assisted surgery}

Employing laparoscopic or thoracoscopic access in esophagectomy has its disadvantages related to, e.g., the limitations of the used instruments, narrow operative space in the mediastinum, and 2D imaging. The introduction of robotic techniques (3D imaging, articulated surgical tools) has created an opportunity for a significant improvement of MIE operations. Robotically assisted techniques may be employed during the thoracic dissection of the esophagus, gastric mobilization, and the performance of thoracic anastomosis. It may also be used in combination with laparoscopy, manually assisted laparoscopy, or thoracoscopic access. The robotic technique employs a similar set of laparoscopic ports, using $5 \mathrm{~mm}$ trocars instead of $8 \mathrm{~mm}$ ones [15].

\section{Minimally invasive esophagectomy operation results}

In the available literature, the analyzed groups of patients undergoing MIE are small, and the published reports are mainly retrospective comparative studies. Lee et al. assessed the benefits associated with MIE operations, comparing them with open surgery. The data gathered by the authors revealed longer operating times associated with MIE procedures in comparison with HMIE (hybrid minimally invasive esophagectomy; thoracoscopy and laparotomy) and traditional surgery, lower numbers of excised lymph nodes in MIE/HMIE operations in comparison with the open technique, shorter hospitalization time for MIE in comparison with HMIE and open surgery, as well as lower rates of pulmonary complications and anastomotic leaks in the MIE group. No differences with respect to perioperative mortality were found [22]. Luketich et al. from a center in Pittsburg, USA, presented a retrospective analysis of a substantial number of MIE operations. The analyzed material included 1011 patients with esophageal or gastric cardia cancer undergoing video-assisted surgery in the years 1996-2011. Perioperative mortality was $2.8 \%$, while the rate of severe complications did not exceed $6 \%$. The location (distal esophagus/cardia) and histological type of neoplasms (primarily adenocarcinoma) caused the medical team to change the operative strategy - most procedures conducted after 2006 were MIE with thoracic anastomoses. As a result, a decrease in the frequency of recurrent laryngeal nerve palsy was noted - from $8 \%$ to $1 \%$. In the analysis of 481 procedures (48\%) with cervical anastomosis and 530 procedures (52\%) with thoracic anastomosis, no differences were found in perioperative mortality and the frequency of other perioperative complications. Oncological radicality was achieved in both operative techniques in $98 \%$ of patients; the mean number of excised lymph nodes was 21 . These figures are comparable to the best results achieved in experienced centers performing open esophageal resections. These data prove that MIE is a safe method, improving the postoperative course and resulting in shorter hospital stay [23]. Bierre et al. conducted a meta-analysis comparing two groups of operations: $1-$ operation via thoracoscopic-laparoscopic approach (MIE) vs. right-sided thoracotomy with laparotomy, 2 - thoracoscopic approach with laparotomy (HMIE) vs. right-sided thoracotomy with laparotomy. 1061 patients were included in the assessment. No significant differences in terms of serious approachdependent postoperative or pulmonary complications were found in group 1. In group 2, the patients undergoing HMIE 
experienced significantly fewer anastomotic leaks $(p=0.03)$. A tendency toward lower postoperative mortality among patients undergoing MIE/HMIE was found in both groups. This tendency, however, was not statistically significant [24]. Decker et al. presented the results of an analysis comparing various approaches for esophagectomy. The study encompassed 1932 patients undergoing treatment with MIE and HMIE. In $5.9 \%$ of cases, it was necessary to convert to the open method. The mortality rate in the studied group was $2.9 \%$. The authors did not report any differences between the analyzed methods [25]. According to Butler et al., the MIE thoracic approach provides a significantly better visualization of the esophagus when compared to the transhiatal approach, making it the preferred option [26]. Dantoc et al., on the basis of the results of 17 publications, estimated that the mean number of lymph nodes excised in MIE operations was higher than in the case of traditional operations; however, this did not have any influence on the patients' survival [27]. Another meta-analysis, performed by Nagpal et al., concerned the results of MIE resections and traditional esophagectomy. The authors did not find any differences in perioperative mortality rates in a group of 672 patients after MIE and 612 patients after traditional resection. The patients after MIE were hospitalized for shorter periods of time, exhibited lower blood loss, and suffered from fewer pulmonary and postoperative complications in total [28]. The results of the first multi-center prospective randomized study comparing the outcomes of MIE with open esophagectomy due to esophageal cancer were published in 2012. The research was conducted in five European centers performing at least 30 esophageal resections a year. A group of 56 patients underwent open surgery, while a group of 59 patients underwent MIE. Respiratory complications were found in 16 patients (29\%) operated on with the traditional method and in 5 patients $(9 \%)$ after MIE $(p=0.005)$. One patient undergoing traditional surgery died as a result of a fistula in the anastomosis. Two patients died in the MIE group. The acquired results prove the significant benefits of MIE in the treatment of patients with resectable esophageal cancer. This study is the only methodologically correct, multi-center clinical study of MIE. It is limited by the lack of long-term outcomes and the fact that its results need to be confirmed by other multi-center, randomized studies [29]. Surgical experience with robotically assisted MIE operations is scarce. De la Fuente et al. published the results of a retrospective analysis of the first 50 MIE procedures performed using the robotically assisted Ivory-Lewis method. The obtained results suggest that robotically assisted esophagectomy is at least as oncologically effective as open surgery. The authors emphasize that such procedures should be performed in specialized centers with a lot of experience with both open esophagectomy and MIE [30]. Despite its tremendous benefits associated with dissecting precision, this modern technique is significantly limited by its low availability and high cost. The potential benefits and controversies related to the implementation of MIE operations in clinical practice are presented in Table II.

\section{Conclusions}

Minimally invasive esophagectomy techniques performed in reference centers conducting large numbers of such procedures constitute an important alternative in the surgical treatment of esophageal cancer patients. The recurrence rates of MIE procedures are similar to those of open surgery. MIE is associated with lower blood loss, less postoperative pain, and shorter hospital and ICU stay. It also enables the patients to return to full activity earlier. There are no detailed data available on the survival time of patients after MIE, which results from the relatively short period of observation. No significant differences in the survival of patients after traditional surgery and MIE have been found to date. The significant limitations of MIE include longer operating time, high cost, and low availability of medical equipment (tools, staplers, robots). The risk of trocar site metastasis should also be taken into consideration. Moreover, MIE techniques are not subject to standardization. The learning curve is long and the number of complica-

Tab. II. Benefits and limitations of laparoscopic thoracic surgery in the treatment of patients with esophageal cancer

\begin{tabular}{ll} 
Minimally invasive esophagectomy - benefits & Minimally invasive esophagectomy - limitations \\
$\begin{array}{l}\text { Smaller external surgical injury } \\
\text { Smaller amount of blood transfusion [28, 32] }\end{array}$ & $\begin{array}{l}\text { Comparable internal surgical injury } \\
\text { Conversion required in } 3 \% \text { to } 18 \% \text { of cases [33, 34] } \\
\text { Longer surgery time [22] }\end{array}$ \\
\hline Lower rate of surgical site infections [36] & $\begin{array}{l}\text { Comparable frequency of pulmonary complications and perioperati- } \\
\text { ve mortality [24, 34] }\end{array}$ \\
Lower rate of respiratory complications [28, 29] & $\begin{array}{l}\text { Comparable rate of anastomotic fistulas [32] } \\
\text { Comparable mean hospitalization time [32] }\end{array}$ \\
\hline $\begin{array}{l}\text { Lower rate of anastomotic fistulas [36] } \\
\text { Shorter mean hospitalization time }[23,28,36]\end{array}$ & \\
\hline
\end{tabular}

No cost analysis - the immediate higher cost of MIE operations (endostaplers) may be compensated by the shorter ICU stay [37] High cost of robotically assisted operations

MIE - oncologically equivalent to open surgery

(similar number of excised lymph nodes [23, 32]

comparable 5-year survival - approx. $40 \%[25,27])$

Long learning curve (> 30 operations);

MIE is preferred by surgeons in high-volume centers [31]

Training surgeons in Polish conditions is difficult 
tions in a given center may initially be higher. It is estimated that a surgeon has to perform at least 30 [31] or even 50 [26] MIE operations to achieve sufficient surgical expertise. The establishment of a single standpoint regarding the selection of an optimal approach in esophagectomy is complicated by the diversity of the available MIE techniques. There is a need for randomized control studies comparing MIE techniques with traditional surgery. Such research should result in the recommendation of a single procedure with the lowest rate of recurrence and complications and the best postoperative quality of life, which would provide an optimal alternative for the surgical treatment of patients with esophageal cancer.

\section{References}

1. http://www.onkologia.org.pl/pl/p/7/

2. Ferlay J, Shin HR, Bray F, Forman D, Mathers C, Parkin DM. GLOBOCAN 2008 v1.2, Cancer Incidence and Mortality Worldwide: IARC CancerBase No. 10 [Internet] Lyon, France: International Agency for Research on Cancer, 2010; available at: http://globocan.iarc.fr.

3. Birkmeyer JD, Siewers AE, Finlayson EV, Stukel TA, Lucas FL, Batista I, Welch HG, Wennberg DE. Hospital volume and surgical mortality in the United States. N Engl J Med 2002; 346: 1128-1137.

4. Poon RT, Law SY, Chu KM, Branicki FJ, Wong J. Esophagectomy for carcinoma of the esophagus in the elderly: results of current surgical management. Ann Surg 1998; 227: 357-364.

5. Thomas P, Doddoli C, Neville P, Pons J, Lienne P, Giudicelli R, Giovannini M, Seitz JF, Fuentes P. Esophageal cancer resection in the elderly. Eur J Cardiothorac Surg 1996; 10: 941-946.

6. Dunst CM, Swanström LL Minimally invasive esophagectomy. J Gastrointest Surg 2010; 14 (suppl): 108-114.

7. Cuschieri A, Shimi S, Banting S. Endoscopic oesophageactomy through a right thoracospoic approach. J R Coll Surg Edinb 1992; 37: 7-11.

8. Collard JM, Lengele B, Otte JB, Kestens PJ. En bloc and standard esophagectomies by thoracoscopy. Ann Thorac Surg 1993; 56: 675-679.

9. Krasna MJ, Jiao X, Mao YS, Sonett J, Gamliel Z, Kwong K, Burrows W, Flowers JL, Greenwald B, White C. Thoracoscopy/laparoscopy in the staging of esophageal cancer: Maryland experience. Surg Laparosc Endosc Percutan Tech 2002; 12: 213-218.

10. Nwomeh BC, Luketich JD, Kane TD. Minimally invasive esophagectomy for caustic esophageal stricture in children. J Pediatr Surg 2004; 39: 1-6.

11. Goldberg RF, Bowers SP, Parker M, Stauffer JA, Asbun HJ, Smith CD. Technical and perioperative outcomes of minimally invasive esophagectomy in the prone position. Surg Endosc 2013; 27: 553-557.

12. Pennathur A, Awais O, Luketich JD. Minimally invasive esophagectomy for Barrett's with high-grade dysplasia and early adenocarcinoma of the esophagus. J Gastrointest Surg 2010; 14: 948-950.

13. Fernando HC, Luketich JD, Buenaventura PO, Perry Y, Christie NA. Outcomes of minimally invasive esophagectomy (MIE) for high-grade dysplasia of the esophagus. Eur J Cardiothorac Surg 2002; 22: 1-6.

14. Inoue H, Minami H, Kaga M, Sato Y, Kudo SE. Endoscopic mucosal resection and endoscopic submucosal dissection for esophageal dysplasia and carcinoma. Gastrointest Endosc Clin N Am 2010; 20: 25-34.

15. Yamamoto M, Weber JM, Karl RC, Meredith KL. Minimally invasive surgery for esophageal cancer: review of the literature and institutional experience. Cancer Control 2013; 20: 130-137.

16. Gossot D, Toledo L, Cortes A. Minimal access esophagectomy: where are we up to? Semin Laparosc Surg 2000; 7: 2-8.
17. Luketich JD, Schauer PR, Christie NA, Weigel TL, Raja S, Fernando HC, Keenan RJ, Nguyen NT. Minimally invasive esophagectomy. Ann Thorac Surg 2000; 70: 906-912.

18. Jaroszewski DE, Williams DG, Fleischer DE, Ross HJ, Romero Y, Harold KL An early experience using the technique of transoral OrVil EEA stapler for minimally invasive transthoracic esophagectomy. Ann Thorac Surg 2011; 92: 1862-1869.

19. Hoppo T, Jobe BA, Hunter JG. MIE: The evolution and technique if minimally invasive surgery for esophageal cancer. World J Surg 2011; 35: 1454-1463.

20. Law S, Wong J. Therapeutic options for esophageal cancer. J Gastroenterol Hepatol 2004; 19: 4-12.

21. Law S, Fok M, Chu KM, Wong J. Thoracoscopic esophagectomy for esophageal cancer. Surgery 1997; 122: 8-14.

22. Lee JM, Cheng JW, Lin MT, Huang PM, Chen JS, Lee YC. Is there any benefit to incorporating a laparoscopic procedure into MIE? The impact on perioperative results in pts with esophageal cancer. World J Surg 2011; 35: 790-797.

23. Luketich JD, Pennathur A, Awais O, Levy RM, Keeley S, Shende M, Christie NA, Weksler B, Landreneau RJ, Abbas G, Schuchert MJ, Nason KS. Outcomes after minimally invasive esophagectomy: review of over 1000 patients. Ann Surg 2012; 256: 95-103.

24. Biere SS, Cuesta MA, van der Peet DL. Minimally invasive versus open esophagectomy for cancer: a systematic review and meta-analysis. Minerva Chir 2009; 64: 121-133.

25. Decker G, Coosemans W, De Leyn P, Decaluwé H, Nafteux P, Van Raemdonck D, Lerut T. Minimally invasive esophagectomy for cancer. Eur J Cardiothorac Surg 2009; 35: 13-20.

26. Butler N, Collins S, Memon B, Memon MA. Minimally invasive oesophagectomy: current status and future direction. Surg Endosc 2011; 25: 2071-2083.

27. Dantoc MM, Cox MR, Eslick GD. Does minimally invasive esophagectomy (MIE) provide for comparable oncologic outcomes to open techniques? A systematic review. J Gastrointest Surg 2012; 16: 486-494.

28. Nagpal K, Ahmed K, Vats A, Yakoub D, James D, Ashrafian H, Darzi A, Moorthy $\mathrm{K}$, Athanasiou T. Is minimally invasive surgery beneficial in the management of esophageal cancer? A meta-analysis. Surg Endosc 2010; 24: 1621-1629.

29. Biere SS, van Berge Henegouwen MI, Maas KW, Bonavina L, Rosman C, Garcia JR, Gisbertz SS, Klinkenbijl JH, Hollmann MW, de Lange ES, Bonjer HJ, van der Peet DL, Cuesta MA. Minimally invasive versus open oesophagectomy for patients with oesophageal cancer: a multicentre, open-label, randomised controlled trial. Lancet 2012; 379: 1887-1892.

30. de la Fuente SG, Weber J, Hoffe SE, Shridhar R, Karl R, Meredith KL Initial experience from a large referral center with robotic-assisted Ivor Lewis esophagogastrectomy for oncologic purposes. Surg Endosc 2013; 27: 3339-3347.

31. Enestvedt CK, Perry KA, Kim C, McConnell PW, Diggs BS, Vernon A, O'Rourke RW, Luketich JD, Hunter JG, Jobe BA. Trends in the management of esophageal carcinoma based on provider volume: treatment practices of 618 esophageal surgeons. Dis Esophagus 2010; 23: 136-144.

32. Noble F, Kelly JJ, Bailey IS, Byrne JP, Underwood TJ; South Coast Cancer Collaboration - Oesophago-Gastric (SC3-OG). A prospective comparison of totally minimally invasive versus open Ivor Lewis esophagectomy. Dis Esophagus 2013; 26: 263-271.

33. Song SY, Na KJ, Oh SG, Ahn BH. Learning curves of minimally invasive esophageal cancer surgery. Eur J Cardiothorac Surg 2009; 35: 689-693.

34. Nguyen NT, Hinojosa MW, Smith BR, Chang KJ, Gray J, Hoyt D. Minimally invasive esophagectomy: lessons learned from 104 operations. Ann Surg 2008; 248: 1081-1091.

35. Perry KA, Enestvedt CK, Pham T, Welker M, Jobe BA, Hunter JG, Sheppard BC. Comparison of laparoscopic inversion esophagectomy and open transhiatal esophagectomy for high-grade dysplasia and stage I esophageal adenocarcinoma. Arch Surg 2009; 144: 679-684.

36. Ben-David K, Sarosi GA, Cendan JC, Howard D, Rossidis G, Hochwald SN. Decreasing morbidity and mortality in 100 consecutive minimally invasive esophagectomies. Surg Endosc 2012; 26: 162-167.

37. Herbella F, Patti M. Minimally invasive esophagectomy World J Gastroenterol 2010; 16: 3811-3815. 